\title{
Analisis Sistem Informasi Manajemen pada Portal Student di STIE STEMBI Bandung
}

\author{
Aulia TAZKIYA \\ Fakultas Ekonomi, STIE STEMBI Bandung Business School, \\ Jalan Buah Batu No.26 Burangrang Kec. Lengkong Kota Bandung, Jawa Barat, Indonesia \\ auliatazkiya20@student.STEMBI.ac.id \\ Mico ALDIANSYAH \\ Fakultas Ekonomi, STIE STEMBI Bandung Business School, \\ Jalan Buah Batu No.26 Burangrang Kec. Lengkong Kota Bandung, Jawa Barat, Indonesia \\ micoaldiansyah20@Student.STEMBI.ac.id \\ Ricky FIRMANSYAH \\ Universitas Ars, \\ Jalan Sekolah Internasional No. 1-2 Bandung, Jawa Barat, Indonesia \\ ricky@ars.ac.id
}

Article's history:

Received 26 December 2020; Received in revised form 21 January 2021; Accepted 29 January, 2021; Published 28 February 2021. All rights reserved to the Lembaga Otonom Lembaga Informasi dan Riset Indonesia (KITA INFO dan RISET).

Suggested citation:

Tazkiya, A., Aldiansyah, M., Firmansyah, R. 2021. Analisis Sistem Informasi Manajemen pada Portal Student di STIE STEMBI Bandung. JEMSI (Jurnal Ekonomi, Manajemen, dan Akuntansi), Volume 7 (1): 17-26. DOI: https://doi.org/10.35870/jemsi.v7i1.513.

\begin{abstract}
ABSTRAK:
Teknologi informasi berampak terhadap manajemen dari segala bidang tidak terkecuali dalam bidang pendidikan Banyak sekali instansi pendidikan yang menggunakan sistem informasi manajemen dalam mengelola lembaganya. Demikian halnya di STIE STEMBI Bandung yang juga merupakan institusi pendidikan, tentunya harus meningkatkan kualitas layanan terhadap jasa pendidikan yang diberikan. Salah satunya dengan penggunaan sistem informasi manajemen. STIE STEMBI Bandung memanfaatkan sistem informasi manajemen baik dalam kegiatan akademik maupun non akademik dengan tujuan agar mahasiswa maupun para staf pegawai mampu melakukan aktivitasnya dengan lebih efektif dan efisien. Berdasarkan hasil wawancara langsung terhadap pengelola STIE STEMBI Bandung, didapatkan keterangan bahwa STIE STEMBI Bandung menggunakan Portal Student sebagai sistem informasi akademik bagi mahasiswa. Tujuan Penelitian ini dilakukan adalah untuk mengetahui analisis sistem informasi manajemen pada Portal Student di STIE STEMBI Bandung. Jenis analisis yang digunakan adalah analisis PIECES yaitu analisis terhadap 6 kriteria, seperti kinerja (Performance), informasi (Information), ekonomi (Economic), kontrol (Control), efisiensi (Efficiency), dan pelayanan (Services). Metode yang digunakan adalah metode penelitian kualitatif dengan pendekatan studi kasus (case study). Adapun langkah-langkah pengumpulan data penelitian ini dilakukan dengan observasi, angket terhadap 25 responden yang merupakan mahasiswa STIE STEMBI Bandung yang pernah menggunakan Portal Student, wawancara terhadap pengelola Portal Student di STIE STEMBI Bandung, studi kepustakaan dan triangulasi. Hasil Analisis menunjukkan bahwa Portal Student memiliki banyak manfaat dan kelebihan dalam menunjang kebutuhan informasi khususnya bagi mahasiswa.
\end{abstract}

Kata Kunci: Analisis; Sistem Informasi Manajemen; Portal Student.

JEL Classification: L86; D83 ; 123. 


\section{PENDAHULUAN}

Teknologi informasi dewasa ini bertumbuh begitu pesatnya. Penggunaan teknologi informasi sudah menjadi suatu kebutuhan, tidak hanya sekedar lifestyle atau kapasitas sebagian orang (Nasrullah , 2015). Pemanfaatan teknologi informasi akan berpengaruh terhadap kinerja suatu organisasi dalam mencapai tujuannya. Selain itu, teknologi informasi juga berampak terhadap manajemen dari segala bidang tidak terkecuali dalam bidang pendidikan. Seluruh instansi pendidikan akan menggunakan sistem informasi manajemen dalam mengelola lembaganya. Fungsi dari sistem informasi manajemen ini adalah untuk menghimpun, mengolah, serta membagikan informasi kepada anggota dari sebuah organisasi.

Demikian halnya di STIE STEMBI Bandung yang juga merupakan institusi pendidikan, tentunya harus meningkatkan kualitas layanan terhadap jasa pendidikan yang diberikan. Salah satunya dalam penggunaan sistem informasi manajemen. STIE STEMBI Bandung memanfaatkan sistem informasi manajemen baik dalam kegiatan akademik maupun non akademik dengan tujuan agar mahasiswa maupun para staf pegawai mampu melakukan aktivitasnya dengan lebih efektif dan efisien. Tahapan kegiatan akademik di STIE STEMBI Bandung diawali dengan pendaftaran mahasiswa, kemudian mendapatkan NPM (Nomor Pokok Mahasiswa) dan selajutnya diarahkan masuk ke dalam AIS (Academic Information system) sampai ia dinyatakan lulus. AIS atau dalam bahasa Indonesia, Sistem informasi akademik (SIAKAD) merupakan salah satu katagori dari sistem informasi manajemen yang merujuk pada seperangkat aktivitas atau sistem yang dirancang untuk keperluan pengeloan data-data akademik dengan penerapan teknologi komputer, sehingga seluruh proses kegiatan akademik dapat diolah menjadi informasi yang bermanfaat dalam pengambilan keputusan manajemen di lingkungan perguruan tinggi (Hakim, 2019).

Berdasarkan hasil wawancara langsung terhadap pengelola STIE STEMBI Bandung, didapatkan keterangan bahwa STIE STEMBI Bandung menggunakan Portal Student sebagai sistem informasi akademik bagi mahasiswa. Portal Student sebagai sistem informasi berbasis teknologi informasi ini telah digunakan sejak tahun 2004 dan terus dalam pengembangan. Sistem ini dapat diakses melalui web browser seperti Mozilla Firefox, Google Chrome, Opera dan lain sebagainya oleh seluruh civitas academica STIE STEMBI Bandung. Pada dasarnya Portal Student berfungsi sebagai media seluruh agenda kegiatan perkuliahan, seperti sarana komunikasi antara pembimbing dan mahasiswa, proses pembelajaran, absensi, input dan output data mahasiswa dan semacamnya. Namun seiring dengan banyaknya pembaruan dan tuntutan kebutuhan, akhirnya ada beberapa fitur dari Portal Student yang tidak digunakan dan kemudian dipisahkan pada aplikasi-aplikasi yang lain, misalnya untuk proses pembelajaran seperti absensi, penyampaian materi dan pengumpulan tugas kini menggunakan LMS yang sebelumnya menggunakan Google Class Room, sehingga Portal Student hanya digunakan sebagai lalulintas data saja. Berdasarkan pada latar belakang ini, kami tertarik untuk mengetahui bagaimana portal Student sebagai sebuah Sistem Informasi manajemen mampu memenuhi kebutuhan informasi untuk para penggunanya khususnya bagi para mahasiswa STIE STEMBI Bandung. Di samping itu, penelitian ini juga bertujuan untuk memberikan evaluasi terhadap suatu sistem informasi. Dengan demikian, diperlukan analisis sistem secara detail dan menyeluruh untuk mendapat perhatian khusus agar kekuatan dan kelemahan sistem dapat diketahui. Harapannya, hasil penelitian ini dapat dijadikan referensi bagi kemajuan perguruan tinggi selanjutnya (Syahputra, 2019). Analisis yang digunakan dalam penelitian ini adalah analisis PIECES, yaitu penyelidikan terhadap 6 kategori, seperti Performance (Kinerja sistem), Information (Informasi), Economics (Ekonomi), Control (Pengaturan), Efficiency (Efisiensi), dan yang terakhir Service (Layanan).

\section{TINJAUAN KEPUSTAKAAN}

\section{Pengertian Analisis}

Analisis menurut KBBI (Kamus Besar Bahasa Indonesia) adalah penyelidikan, penelaahan atau penguraian terhadap suatu peristiwa untuk diketahui penyebab dan keadaan sebenarnya. Sedangkan analisis sistem (system analysis) adalah sebuah metode atau teknik memecahkan masalah dengan menguraikan sistem untuk mengetahui kinerja dari komponen-komponen pembentuknya yang saling berinteraksi dan bekerja sama untuk mencapai tujuan sistem. Menurut (Syfnidawaty, 2020) analisis sistem adalah penjabaran dari sebuah sistem informasi yang lengkap ke dalam berbagai macam bagian komponennya dengan tujuan agar berbagai masalah yang timbul dari sistem dapat diidentifikasi dan dievaluasi. 


\section{Sistem Informasi Manajemen}

Sistem informasi manajemen (SIM) atau management information system (MIS) adalah sekumpulan komponen dalam sistem informasi yang mengekstrak data menjadi informasi dengan mengintegrasikan komponen sistem informasi berupa orang, perangkat keras, perangkat lunak, jaringan komunikasi dan sumber daya data. Menurut Barry E. Cushing SIM merupakan kumpulan manusia beserta sumber daya modal yang bertanggungjawab menghimpun dan mengolah data untuk menghasilkan informasi yang akan digunakan oleh seluruh tingkatan manajemen di dalam suatu organisasi pada kegiatan perencanaan dan pengendalian (Sudirman, 2020).

Gordon B. Davis dalam (Milka, 2014) menyatakan SIM adalah sistem manusia atau mesin yang menyediakan informasi untuk mendukung operasi manajemen dan fungsi pengambilan keputusan dari suatu organisasi. Selain itu menurutnya, SIM selalu memiliki kaitan dengan pengolahan informasi berbasis komputer (computer-based information processing). SIM melakukan fungsi-fungsi sistem untuk menyediakan seluruh informasi yang dapat memberikan pengaruh terhadap operasi organisasi (Prasojo, 2013). Singkatnya SIM dapat dikatakan sebagai kumpulan interaksi berbagai sistem informasi yang menyediakan informasi baik untuk kebutuhan manajerial maupun kebutuhan operasi.

\section{Komponen-komponen dalam SIM}

Komponen-komponen yang saling berkalitan membangun sistem informasi manajemen, meliputi:

1. Manusia

Manusia memiliki peran penting dalam Sistem Informasi Manajemen, yaitu perencanaan, perancangan, pembangunan, pengoprasian, pengelolaan, serta perbaiakan dari sistem itu sendiri. Informasi yang dihasilkan dari tahapan proses yang dilewati oleh manusia akan memberikan manfaat bagi bisnis yang dijalankan. Sistem Informasi Manajemen akan berjalan dengan baik dan semestinya ketika tersedianya sumber daya manusia yang diperlukan.

2. Sistem

Makna kata "sistem" dapat didefinisikan sebagai kumpulan dari suatu elemen, unsur, komponen atau variabel yang saling berinteraksi untuk mencapai tujuan dengan terorganisasi. Menurut Azhar Susanto dalam (Djahir \& Pratita, 2012) sistem merupakan kumpulan atau grup dari sub sistem/bagian/komponen atau apapun baik fisik ataupun non fisik yang saling berhubungan satu sama lain dan agar bekerja sama untuk mencapai tujuan tertentu. Arifin Rahman juga berpendapat bahwa sistem adalah kumpulan pendapat, sism, dan hal-hal lain yang membentuk satu kesatuan yang saling berhubungan. Tiga aktivitas dasar sistem dalam sistem informasi manajemen berupa input, processing, dan output akan menghasilkan informasi yang berguna sekaligus dibutuhkan perusahaan untuk pengambilan keputusan berikutnya baik untuk pengendalian operasional kerja, dalam hal analisa permasalahan perusahaan maupun keputusan dalam menciptakan produk baru.

3. Informasi

Informasi adalah hasil olahan data menjadi bentuk yang lebih berarti atau lebih berguna bagi penerimanya. Synanski dan Pulschen dalam (Handayani, 2017) berpendapat bahwa informasi adalah pemrosesan data yang terlihat dalam konteks untuk memberikan arti kepada orang lain. Sebuah informasi mampu menjelaskan kondisi yang telah terjadi, sedang terjadi atau kemungkinan terjadi di masa mendatang. Terdapat dua hal yang dapat menentukan nilai dari sebuah informasi, yaitu manfaat dan biaya mendapatkannya. Sebuah informasi dapat dikatakan bernilai apabila biaya mendapatkannya lebih kecil dari keefektifan manfaatnya. Fungsi-fungsi informasi adalah sebagai berikut: a). Untuk meningkatkan pengetahuan bagi manajer atau pengguna lainnya b). Untuk meminimalkan ketidakpastian para manajer dalam pengambilan keputusan, sehingga informasi harus mampu memberikan gambaran dan kepastian terhadap sebuah situasi. Sebuah bisnis akan mengalami perkembangan ketika Sistem Informasi Manajemen yang digunakan tepat, karena pengolahan data dan informasi yang dihasilkan akan lebih mudah dan teruji.

4. Organisasi manajemen

Organisasi adalah sebuah wadah bagi sekelompok orang yang terstuktur, bekerja sama dan memiliki tujuan yang sama. Istilah manajemen memiliki berbagai pengertian, namun secara universal manajemen adalah penggunaan sumber daya organisasi untuk mencapai sasaran dan kinerja yang tinggi dalam berbagai tipe organisasi profit maupun non profit. Manajemen dapat juga didefinisikan sebagai kemampuan atau keterampilan untuk memperoleh sesuatu hasil dalam rangka pencapaian tujuan melalui kegiatan-kegiatan orang lain. Manajemen merupakan seni dalam menyelesaikan pekerjaan melalui orang lain. Fungsi dari 
organisasi manajemen sendiri adalah untuk mengatur, melaksanakan, merencanakan, dan mengontrol operasional perusahaan atau organisasi (Wijayanto, 2013).

5. Pengambilan keputusan

Keputusan yang tepat salah satunya dapat dihasilkan dari informasi yang dapat dipertanggungjawabkan. Pengambilan keputusan oleh seorang pebisnis maupun pengusaha harus didasarkan pada informasi yang tersedia dalam sistem informasi manajemen yang digunakan sehingga informasi harus bersifat fakta dan relevan, tidak boleh ada unsur rekayasa.

\section{Model Sistem Informasi Manajemen}

Sebagai panduan, berikut diuraikan beberapa bentuk sistem informasi manajemen yang banyak dan telah digunakan oleh perusahaan maupun lembaga lainnya dalam menunjang aktivitas manajemen.

1. Enterprise Resource Planning (ERP) adalah sistem perangkat lunak modular yang digunakan untuk mengintegrasi atau mengotomasi proses-proses bisnis atau usaha yang merupakan fungsi utama dalam sebuah sistem yang komples dan terpadu.

2. Supply Chain Management (SCM) adalah aktivitas rantai pasok yang meliputi perencanaan dan kegiatan manajemen logistik untuk memaksimalkan customer value dan keunggulan persaingan yang berkelanjutan (Putradi, 2020).

3. Transaction Processing System (TPS) adalah sebuah sistem yang sangat berguna dalam pengumpulan dan pengelolaan data dalam jumlah yang besar dan transaksi yang rutin. Rancangan ini biasa diaplikasikan dalam manajemen gaji dan inventaris.

4. Office Automation System (OAS) adalah sebuah aplikasi ini berguna untuk memperlancar komunikasi antar departemen dalam suatu perusahaan dengan cara menginterferensikan server-server komputer pada setiap user di perusahaan. Contohnya seperti email.

5. Knowledge Work System (KWS) adalah integrasi dari suatu informasi maupun pengetahuan baru ke seluruh perusahaan/organisasi/substansi.

6. Informatic Management System (IMS) berfungsi mendukung spektrum tugas-tugas pembuatan keputusan dengan menggunakan program komputerisasi seperti e-procuretment dan menyatukan beberapa fungsi informasi.

7. Decision Support System (DSS) dalam bahasa indonesia Sistem Pendukung Keputusan, membantu manajer mengambil keputusan melalui pengamatan lingkungan di dalam perusahaan. Contohnya seperti link elektronik.

8. Expert System (ES) dan Artificial Intellegent (Al) merupakan sistem yang memiliki kecerdasan buatan dengan menggunakan pengetahuan tenaga ahli yang diprogram untuk manganalisa pemecahan masalah. Contohnya sistem jadwal mekanik.

9. Group Decision Support System (GDSS) dan Computer-Support Collaborative Work System (CSCWS). GDSS hampir sama menyerupai DSS, perbedanya adalah GDSS mencari solusi permasalahan melalui pengumpulan pengetahuan biasanya dalam bentuk kuesioner, konsultasi, dan skenario dalam suatu kelompok, bukan per individu. Contohnya seperti e-government.

10. Executive Support System (ESS) merupan sistem yang membantu manajer dengan berinteraksi melalui bantuan grafik dan alat pendukung komunikasi lainya lingkungan perusahaan. Sistem ini menggunakan bantuan jurnal yaitu software akuntansi online berbasis cloud sehingga memungkinkan data tersimpan secara otomatis.

\section{Portal Student}

Portal Student adalah bagian dari Sistem Informasi Manajemen yang digunakan dalam mengolah data akademik yang berkaitan dengan aktivitas mahasiswa. Portal Student dapat diakses dengan koneksi internet menggunakan web browser seperti Mozilla Firefox, Google Chrome dan sebagainya yang dapat digunakan di mana saja dengan cara mengetikan alamat URL (Unifrom Resource Locator) pada address bar yang tersedia. Pengoptimalan penggunaan portal Student agar berjalan baik tanpa jeda/buffering disarankan menggunakan koneksi internet yang stabil. Pemanfaatan Portal Student harus disesuaikan dengan standar kebutuhan akademik perguruan tinggi agar mahasiswa/pengguna lebih mudah dalam melakukan transaksi yang dibutuhkan (User Friendly). Selain itu, pendekatan teknologi responsive application yang digunakan memungkinkan akses dilakukan menggunakan perangkat mobile phone ataupun gadget lainnya dengan tampilan yang sudah disesuaikan mengikuti layar dari perangkat yang digunakan sehingga tidak merusak tampilan aplikasi. Prinsip menerapkan 
sistem ERP Campus memungkinkan setiap transaksi maupun perubahan yang dilakukan memiliki kolerasi dan keterkaitan dengan sistem lainnya. Sistem informasi manajemen pada Portal Student dengan sistem online ini, dapat digunakan dan dapat dimanfaatkan oleh seluruh civitas academica STIE STEMBI. Bagi mahasiswa, sistem ini dapat digunakan untuk melihat biodata, melihat nilai, KRS online, Evaluasi Dosen oleh Mahasiswa (EDOM), jadwal kuliah dan informasi akademik lainnya. Bagi dosen, sistem ini dapat digunakan untuk melihat biodata, aktivitas mengajar, dosen wali, KRS, menginput data nilai, bahan kuliah, tugas kuliah serta data akademik lainnya.

\section{METODE PENELITIAN}

\section{Metode Penelitian}

Metode kualitatif merupakan jenis metode penelitian yang menekankan pada pengamatan fenomena dan lebih mengamati subtansi makna dari sebuah peristiwa (Ardianto, 2019). Metode kualitatif ini menggunakan pendekatan studi kasus (case study) dengan tujuan agar penelitian dilakukan terhadap satu kesatuan sistem berupa program, kegiatan, peristiwa atau sekelompok individu yang terkait oleh tempat, waktu atau hubungan tertentu (Anwar, 2021). Selain itu, analisis dan ketajaman penelitian kualitatif sangat terpengaruh pada kekuatan kata dan kalimat yang digunakan (Rukin, 2019).

Langkah-langkah pengumpulan data penelitian dilakukan dengan observasi, angket, wawancara, studi kepustakaan dan triangulasi. Observasi dalam penelitian bertujuan untuk mengamati secara langsung bagaimana fenomena terjadi di lapangan. Angket yang digunakan berupa daftar pertanyaan tertulis yang diajukan tentang fenomena yang diteliti kepada 25 responden yang merupakan mahasiswa STIE STEMBI Bandung yang pernah menggunakan Portal Student. Selanjutnya metode pengumpulan data dilakukan dengan wawancara terhadap pengelola Portal Student di STIE STEMBI Bandung. Jenis wawancara yang dilakukan adalah wawancara tidak terstruktur, karena peneliti tidak menggunakan pedoman wawancara yang disusun secara sistematis sebelumnya. Pedoman yang digunakan dalam wawancara jenis ini hanyalah gambaran umum dari pertanyaan yang akan diajukan (Nugraha, 2021). Sebagian informasi dalam penelitian ini juga diperoleh dari hasil kajian terhadap beberapa literatur yang berkaitan dengan sistem informasi manajemen dan tulisan-tulisan lain yang memiliki kaitan dengan landasan teori. Triangulasi dalam penelitian kualitatif dimaksudkan untuk mencocokkan kebenaran data/informasi yang diperoleh peneliti dari berbagai sudut pandang yang berbeda dengan cara mengurangi sebanyak mungkin simpangan yang terjadi pada saat pengumpulan analisis data.

\section{Metode Analisis PIECES}

Untuk mengetahui suatu sistem itu layak atau tidak, diperlukan suatu analisis yang mampu mengidentifikasi kelemahan sistem dan memberikan rekomendasi perbaikan yang mampu dikembangkan. Jenis analisis semacam ini lebih dikenal sebagai Analisis PIECES.

1. Performance (Analisis Kinerja)

Ketika tugas bisnis yang dilakukan tidak memenuhi target, masalah kinerja akan terjadi. Kinerja diukur dengan dua komponen penting yaitu:.

a. Throughput adalah jumlah pekerjaan yang dapat diselesaikan dalam jangka waktu tertentu.

b. Waktu respons adalah penundaan rata-rata antara transaksi dan respons yang diberikan untuk transaksi itu

2. Information (Analisis Informasi)

Kualitas informasi yang baik dapat dinilai dengan perbaikan pada prosedur yang berupa peningkatan manfaat informasi. Penyajian informasi harus benar-benar memiliki nilai yang berguna. Kualitas informasi dapat dilihat dari beberapa faktor berikut:

a. Output (keluaran), sebaik apa sebuah sistem mampu menyajikan informasi yang dibutuhkan.

b. Input (masukan), sebaik apa data dapat dimasukkan kemudian diproses menjadi sebuah informasi.

c. Stored Data (data yang disimpan), sebaik apa sebuah sistem mampu menyimpan data

3. Economic (ekonomi)

Mengukur apakah dalam pelaksanaannya, sistem berjalan dengan biaya yang sebanding dengan manfaat yang didapat.

4. Control (pengendalian)

Mengukur prosedur mana yang masih bisa ditingkatkan dengan mendeteksi kesalahan atau kecurangan agar kualitas pengendalian semakin baik. 
5. Efficiency (efisiensi)

Mengukur bagaimana sebuah sistem informasi mampu memenuhi kebutuhan sebaik mungkin dengan pengorbanan paling minimum sehingga menghindari menjalankan kegiatan yang terlalu berlebihan.

6. Service (layanan)

Analisis layanan dapat diukur dengan seberapa baik sistem menghasilkan informasi yang akurat, konsisten, terpercaya, mudah dimengerti dan tidak kaku. Lebih mudahnya adalah mengukur kemampuan sistem dalam pencapai peningkatan kualitas layanan.

\section{HASIL PENELITIAN DAN PEMBAHASAN}

\section{Analisis Sistem}

STIE STEMBI Bandung memiliki sistem informasi Akademik berbasis situs web yang dapat diakses dengan laman http://STEMBI.ac.id/. Laman tersebut menyediakan beberapa portal seperti: Portal EAcademic yang dapat diakses oleh superuser untuk mengatur keseluruhan sistem, Portal Library yaitu portal yang diperuntukkan bagi pengelola perpustakaan, Portal SPM ( Sistem Penjamin Mutu) yang digunakan bagi pengembang mutu, Portal Student yang diperuntukan bagi mahasiswa, kemudian Portal Lecturer yang dapat diakses oleh para dosen dan yaitu terakhir yaitu Portal Alumni yang yang menyediakan profil, berita, pengumuman, agenda, dan download center serta data base alumni. Berikut ini adalah tampilan dari sistem informasi akademik di STIE STEMBI Bandung.

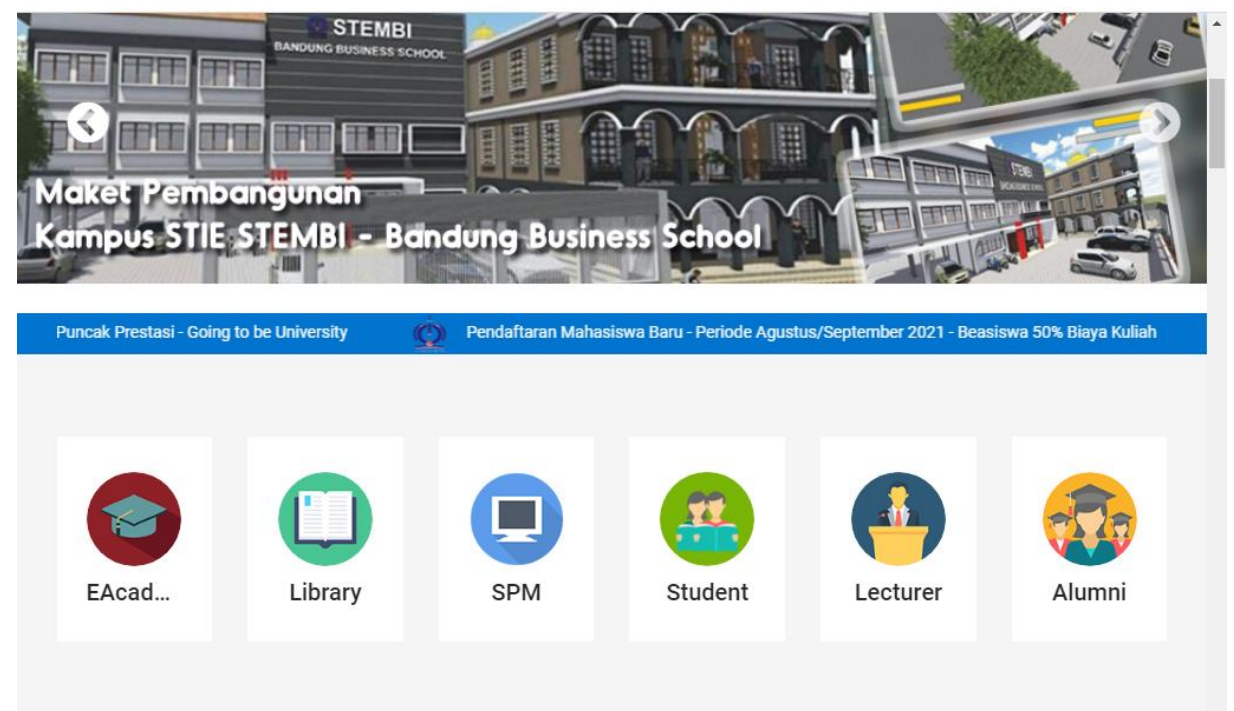

Gambar 1. Tampilan situs web SIM STIE STEMBI Bandung

\section{Analisis Portal Student}

Portal Student adalah bagian dari Sistem Informasi Akademik yang digunakan untuk mengolah data akademik yang berkaitan dengan mahasiswa. Setiap mahasiswa diberikan username dan password yang digunakan untuk mengakses portal. Jika langkah tersebut berhasil dilakukan, selanjutnya akan masuk ke dalam dashboard Portal Student, didalamnya terdapat menu bar, ikon pintasan dan form pengumunman. Menu bar terdiri atas menu beranda, akun, civitas, keuangan, fasilitas, keluhan, dan keluar. Pada ikon pintasan memuat profil, bimbingan, jadwal, dan facility. Bagian lain yang terdapat dari dashboar adalah papan pengumuman yang memuat informasi dan himbauan terkait perkuliah bagi mahasiswa. 


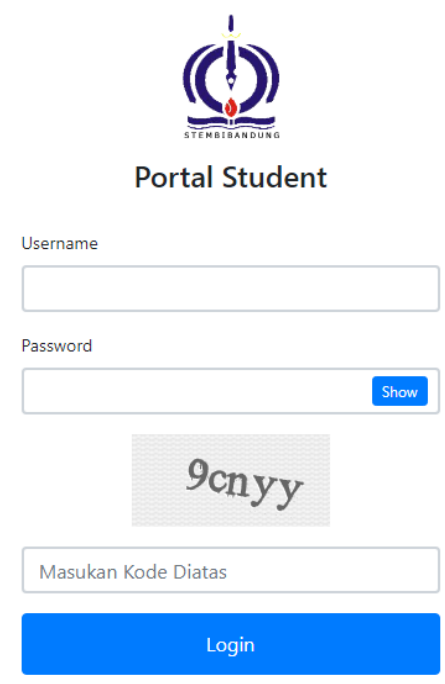

Gambar 2. Tampilan Login

\section{(ci) ) STIE STEMBI - BANDUNG BUSINESS SCHOOL}

Beranda Akun- Civitas- Aktivitas- Keuangan- Fasilitas Keluhan Keluar

Selamat Datang, Aulia Tazkiya

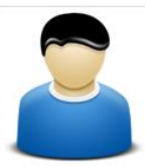

Profil

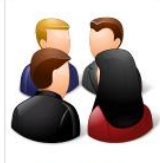

Bimbingan

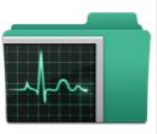

Jadwal

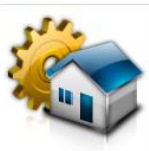

Facility

\section{Pengumuman}

PENGUMUMAN KEUANGAN (Pengumuman) Perubahan Rekening Pembayaran Biaya Kuliah Bank BRI Syariah No Rekening 1030 573745 a.n Yayasan Puncak Prestasi

Attachment : pengumuman-keuanganpengumuman-29082019.docx

Gambar 3. Tampilan dashboard Portal Student

Tabel 1. Bagian-bagian dari dashoboard Portal Student

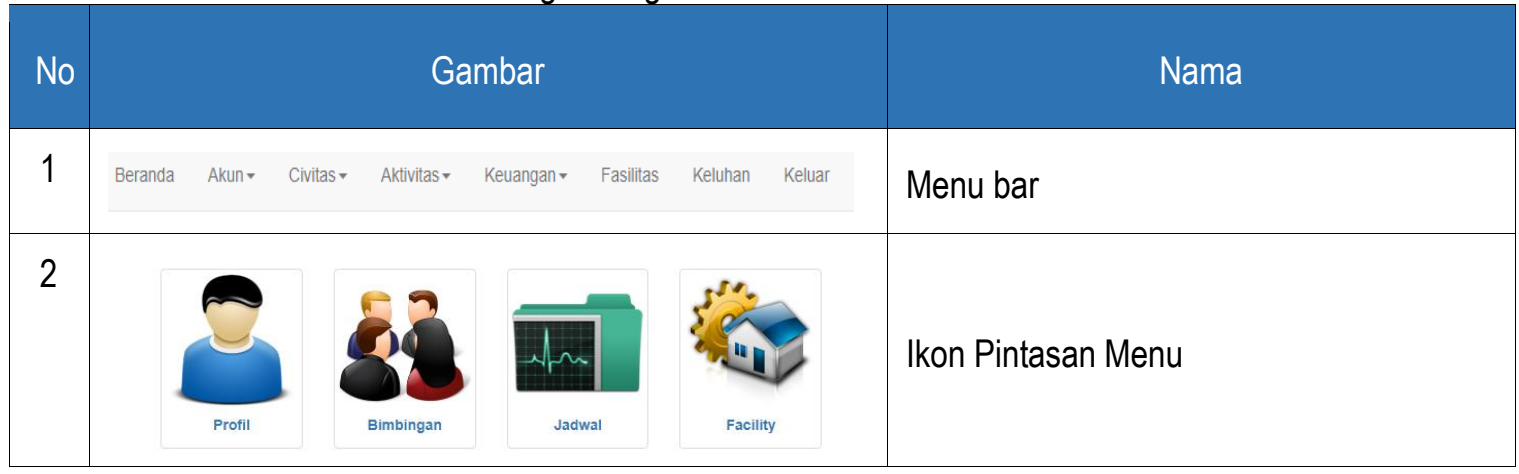




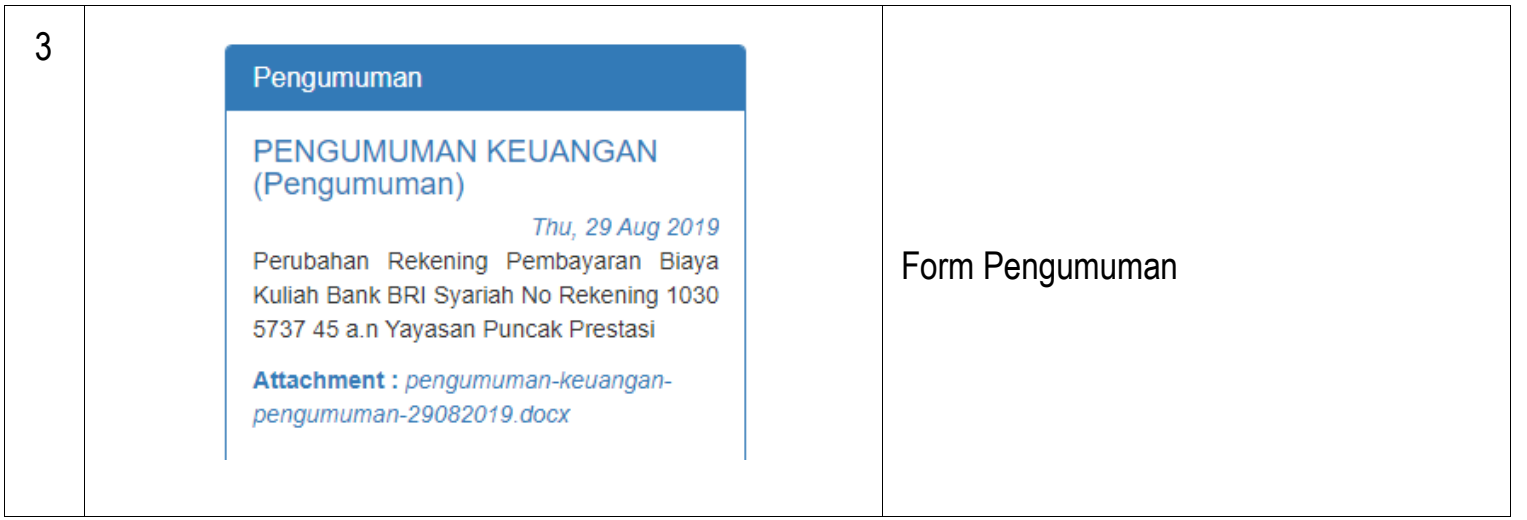

Menu Akun menyajikan dua pengaturan yang perubahan datanya dapat diinput langsung oleh pengguna yakni mahasiawa, terdiri atas pengaturan profil dan pengaturan password. Menu Civitas adalah fasilitas yang digunakan mahasiswa untuk melakukan interaksi berupa bimbingan akademik.dengan dosen. Menu Aktivitas meliputi pengisisan KRS, Cetak KRS, Jadwal kuliah, materi absensi, KHS, Transkip, Jadwal Ujian, Sidang usulan penelitian, Evaluasi dosen, dan Evaluasi institusi. Menu keuangan menyajikan rekap tagihan dan rician pembayaran biaya perkuliahan. Menu keluhan dapat digunakan oleh mahasiswa untuk melakukan konfirmasi atas ketidaksesuaian data / informasi yang terdapat pada portal. Dan menu keluar digunakan untuk keluar/logout dari portal Student.

\section{Analisis PIECES}

Analisis Portal Student dalam aspek perfomence (kinerja sistem) adalah kemampuan sistem dalam menyelesaikan proses/perintah dengan cepat agar dapat mencapai sasaran dengan segera. Sebuah kinerja dapat dikatakan layak berdasarkan usulan kebutuhan. Sistem harus mampu menyelesaikan masalah dan menghasilkan informasi yang dibutuhkan. Sistem dengan kinerja yang buruk akan berpengaruh terhadap kualitas informasi yang dihasilkan. Pengukuran kinerja dilakukan terhadap dua aspek penting seperti, jumlah produksi (throughput) dan waktu tanggap (response time) terhadap suatu perintah untuk mengolah data menjadi sebuah informasi. Jumlah produksi keluaran Portal Student dikatagorikan sangat besar karena proses penyimpanan informasi dilakukan oleh sebuah situs web yang dinamis dan dapat diakses kapanpun dan di mana pun. Waktu tanggap Portal Student dalam menyampaikan informasi menggunakan sistem interface sehingga kecepatan aksesnya pun terbilang singkat.

Informasi adalah hal terpenting yang merupakan titik awal untuk mengoreksi keadaan dalam organisasi. kemampuan Portal Student dalam menghasilkan informasi yang akurat, relevan, lengkap, tepat waktu dan dapat diandalkan sangat bermanfaat untuk menciptakan peluang dalam keberhasilan kegiatan akademik di STIE STEMBI Bandung. Hasil analisis terhadap kemampuan Portal Student di STIE STEMBI Bandung meliputi: 1) Akurasi informasi, secara umum Portal Student menyajikan seluruh informasi kegiatan STIE STEMBI Bandung dapat berupa pengumuman maupun berita terkait internal STIE STEMBI Bandung. 2) Relevan informasi/data, dengan adanya portal Student sangat membantu mahasiswa dalam mendapatkan informasi yang sangat dibutuhkan seputar perkuliahan. 3) kelengkapan informasi, secara keseluruhan dalam sistem informasi yang disediakan STIE STEMBI Bandung dalam Portal Student cukup lengkap dan detail. 4) Ketepatan waktu, dengan sistem informasi manajemen yang digunakan mampu menghemat waktu dalam membagi dan mendapatkan informasi. 5) Keandalan, kemudahan mengakses Portal Student kapanpun dan di mana pun menggunakan perangkat mobile phone, gadget, PC maupun Laptop dengan koneksi internet yang baik akan sangat bisa diandalkan.

Analisis ekonomi mengungkap keberadaan anggara biaya dan manfaatnya, biaya tidak hanya mencakup segi keuangan atau finansial tetapi juga dari segi non-finansial. Keberadaan portal Student sangat menghemat biaya-biaya yang harus dikorbankan untuk mendapatkan informasi, seperti waktu dan biaya transportasi mahasiswa datang ke kempus untuk mencetak KHS, kartu UTS/UAS dan sebagainya dapat dihemat karena dapat dilakukan di mana saja dan kapan saja. Dari hasil wawancara terhadap pengelola Portal Student menghasilkan informasi bahwa analisis biaya operasional dalam pengembangan sistemnya, dikatakan efektif dan wajar, karena manfaat yang didapat sebanding dengan biaya yang dikeluarkan. Hal ini juga disebabkan oleh subjek pengembangan dari sistem tersebut dikerjakan oleh bagian internal institusi sehingga mampu menekan biaya 
pengembangan sistem. Analisis mengenai kontrol dari Portal Student terdapat pada proses pencegahan kesalahan dan kegiatan validasi input dan output. Kegiatan validasi input, proses dan output yang dijalankan menjamin keamanan dan pengontrolan data dan informasi dari portal Student. Kesalahan informasi maupun publikasi dalam Portal Student memiliki kemungkinan yang kecil karena seluruh data diproses oleh bagian pengelola data akademik STIE STEMBI Bandung. Hal ini menjadi penting agar terhindar dari penyalahgunaan data. Kontrol sistem yang berjalan menunjukkan seberapa baik sistem melakukan suatu aktivitas. Semakin sedikit kesalahan yang dilakukan dalam aktivitas, semakin baik tingkat kontrol sistem. Melalui kontrol, tugas dan kinerja yang terganggu dapat diperbaiki.

Efisiensi berhubungan dengan bagaimana sumber daya yang ada dapat digunakan dengan sebaik mungkin dengan pemborosan yang paling minimum. Analisis efisiensi Portal Student berpusat terhadap aspek sasaran yang diinginkan dengan akurasi waktu yang singkat dan tenaga yang cermat. Hal ini dirasakan pada portal Student dengan kemudahan akses layanan yang diberikan mampu mengefisienkan waktu para staf pegawai maupun mahasiswa sebagai pengguna informasi. Selain itu pengurangan penggunaan kertas yang menekan beban logistik karena dilakukan dengan sistem digital adalah bagian dari keefisienan dari Portal Student. Analisis pelayanan Portal Student dirasakan sangat efektif. Keberadaan Portal Student yang terus dievaluasi, dikembangkan dan ditingkatkan diharapkan mampu berkontribusi dalam peningkatan layanan untuk membantu mahasiswa agar terhindar dari birokrasi yang terkesan mempersulit.

\section{Analisis Kelebihan dan Kekurangan Portal Student} berikut:

Adapun kelebihan yang dirasakan mahasiswa STIE STEMBI Bandung dari Portal Student adalah sebagai

1. Portal Student sebagai penyedia informasi yang dinamis dapat diakses kapan dan di mana saja sehingga dirasakan praktis digunakan.

2. Memberikan informasi seputar perkuliahan dengan rinci.

3. Tersedia layanan keluahan dari menu portal Student yang dapat dimanfaatkan untuk mengevaluasi dan meningkatkan kinerja portal Student.

4. Portal student cukup mudah digunakan.

5. Dari segi penampilan desain cukup bagus dan sederhana.

Kelemahan yang dirasakan mahasiswa STIE STEMBI Bandung dari Portal Student adalah sebagai berikut:

1. Sering terjadi down/eror ketika terlalu banyak orang yang mengakses.

2. Sering ada keterlambaran dalam penyampaian KHS.

\section{KESIMPULAN}

STIE STEMBI Bandung memiliki sistem informasi Akademik berbasis situs web yang menyediakan beberapa portal seperti: Portal EAcademic yang dapat diakses oleh superuser untuk mengatur keseluruhan sistem, Portal Library yaitu portal yang diperuntukkan bagi pengelola perpustakaan, Portal SPM ( Sistem Penjamin Mutu) yang digunakan bagi pengembang mutu, Portal Student yang diperuntukan bagi mahasiswa, kemudian Portal Lecturer yang dapat diakses oleh para dosen dan yaitu terakhir yaitu Portal Alumni yang yang menyediakan profil, berita, pengumuman, agenda, dan download center serta data base alumni,

Pembahasan berfokus pada analisis Portal student yang dilakukan dengan teknik PIECES. Analisis PIECES yaitu metode analisis yang dilakukan terhadap 6 kriteria, seperti kinerja (performance), informasi (Information), ekonomi (Economic), kontrol (Control), efisiensi (Efficiency), dan pelayanan (Services). Adapun hasil analisis dari portal student adalah sebagai berikut.

1. Kenerja Portal Student sangat baik, ini dapat dilihat dari jumlah produksi keluaran Portal Student yang dikatagorikan besar. Proses penyimpanan informasinya dilakukan oleh sebuah situs web yang dinamis. Waktu tanggap portal Student dalam menyampaikan informasi menggunakan sistem interface yang mengakibatkan kecepatan akses terbilang singkat.

2. Informasi yang dihasilkan Portal Sudent cukup akurat, relevan, lengkap, dan bisa diandalkan.

3. Portal Student dalam segi pembiayaannya dapat dikatakan efektif dan wajar.

4. Dari segi kontrol, Kesalan informasi maupun publikasi dalam Portal Student memiliki kemungkinan yang kecil karena seluruh data diproses oleh bagian pengelola data akdemik STIE STEMBI Bandung. 
5. Pengurangan penggunaan kertas yang menekan beban logistik karena dilakukan dengan sistem digital dan kemudahan dalam mengaksesnya adalah bagian dari keefisiensian.

6. Portal Student yang terus dievaluasi, dikembangkan dan ditingkatkan diharapkan mampu berkontribusi dalam peningkatan layanan untuk membantu mahasiswa agar terhindar dari birokrasi yang terkesan mempersulit

Adapun kelemahan dari sistem informasi manajemen pada portal student tidak begitu signifikan, terjadinya eror ketika sistem digunakan secara serempak dan adanya keterlambatan penyampaian KHS merupakan hal yang biasa. Namun dengan begitu bukan berarti hal ini tidak menjadi perhatian.

\section{REFERENSI}

[1] Anwar, I. C. (2021, Januari 22). Mengenal Penelitian Kualitatif: Penegertian dan etode Analisis. Retrieved from tirto.id: hpp://tirto.id/mengenal-penelitian-kualitatif-pengertian-dan-metode-analisis-f9vh

[2] Ardianto, Y. (2019, Maret 09). Memahami Metode Penelitian Kualitatif. Retrieved from Retrieved from Kementerian Keuangan Republik Indonesia: https://www.djkn.kemenkeu.go.id/artikel/baca/12773/Memahami-Metode-Penelitian-Kualitatif.html

[3] Djahir, Y., \& Pratita, D. (2012). Bahan Ajar SISTEM INFORMASI MANAEJEMEN. Deepublish.

[4] Hakim, L. (2019). Prinsip-Prinsip Dasar Sistem Informasi Manajemen Dilengkapi Teori Dasar Sistem Informasi Manajemen Pendidikan . Kota Jambi: Timlak Printing .

[5] Handayani, M. A. (2017). Tinjauan tentang Persepsi Mahasiswa terhadap Pelayanan Sistem Informasi Akademik IAIN Purwokerto. KOMUNIKA: Jurnal Dakwah Dan Komunikasi.

[6] Milka, M. P. (2014). Pemanfaatan Sistem Informasi Manajemen di Sekolah Menengah Kejuruan. Jurnal Keguruan dan Ilmu Pendidikan.

[7] Nasrullah , M. (2015). IMPLEMENTASI SISTEM INFIRMASI MANAJEMEN BERBASIS TEKNOLOGI INFORMASI DI UNIVERSITAS NEGERI MAKASSAR. Jurnal Administrasi Publik, 54.

[8] Nugraha, J. (2021, Mei 25). Mengenal Jenis Wawancara, Lengkap Beserta Langkah-langkah dan Tujuannya. Retrieved from merdeka.com: https://www.merdeka.com/jateng/mengenal-jenis-wawancara-lengkapbeserta-langkah-langkah-dan-tujuannya-kln.html

[9] Prasojo, L. D. (2013). Sistem Infotmasi Manajemen Pendidikan. Yogyakarta: UNY Press.

[10] Putradi, C. (2020). Pengertian Supply Chain, Manajemen Rantai Pasok, dan Contoh Proses. Retrieved from MGT Logistik: https://mgt-logistik.com/supply-chain-adalah/

[11] Rukin, S. P. (2019). Metodologi Penelitian Kualitatif. Yayasan Ahmar Cendekia Indonesia.

[12] Sudirman, A. M. (2020). Sistem Informasi Manajemen. Yayasan Kita Menulis.

[13] Syahputra, E. R. (2019). SISTEM INDESK KEPUASAN MAHASISWA (STUDI KASUS: PRODI SISTEM INFORMASI UNIVERSITAS HARAPAN MEDAN). JITEKH (Jurnal IImiah Teknologi Harapan), 7(2), 16-21.

[14] Syfnidawaty. (2020, November 14). Analisis. Retrieved from Universitas Raharja: https://raharja.ac.id/2020/11/14/analisis/

[15] Wijayanto, D. \&. (2013). Pengantar manajemen. Gramedia Pustaka Utama. 